Miloš Lj. Bešić ${ }^{1}$

University of Belgrade

Faculty of Political Sciences

Belgrade (Serbia)
UDC 316.356.2(497.16)"2006/..."

$323.1(497.16) " 2006 / . . . "$

Original scientific paper

Submitted 11/07/2019

Accepted 30/08/2019

doi: 10.5937/socpreg53-22481

\title{
ETHNIC RELATIONS IN MONTENEGRO TWELVE YEARS AFTER GAINING INDEPENDENCE
}

\begin{abstract}
This paper represents an analysis of inter-ethnic relations in Montenegro twelve years after this former Yugoslav republic gained its independence. Ethnic relations are analyzed using the method of ethnic distance measurement. We use empirical data to provide evidence of the level of inter-ethnic and overall ethnic distance in Montenegro. The research and measurement of ethnic distance is based on a traditional Bogardus social distance scale. Besides the descriptive task, the research goal of this paper is to show the effect of political factors on ethic distancing. We test this hypothesis using OLS regression analysis. We found a high level of inter-ethnic distance between Serbs on one side and minorities on the other. We also found a low level of ethnic distance between Montenegrins and Serbs, confirming that the clash between the two is political rather than ethnic by nature.
\end{abstract}

Keywords: Montenegro, ethnic relations, ethnic distance, Bogardus scale, OLS regression analysis

\section{Introduction}

In postwar Yugoslavia, the issue of ethnicity was one of the most important ones in shaping the overall social and political life. It is not an overstatement to say that ethnicity, identification, and ethnic relations were some of the main factors that fueled the dissolution of Yugoslavia (Sekulić, Massey \& Hodson (2006). Furthermore, the nation became the main collective political actor in the process of forming nation-states, which started right after Yugoslavia collapsed (Brubaker, 1996; Bešić, 2001). Each newly formed state was based on national mobilization, and in a multi-ethnic country such as Yugoslavia, this led to inter-ethnic wars (Denitch,1996). Due to this process, relations between ethnic groups in the former Yugoslavia were, and still are, heavily damaged (O'loughlin \& Tuathail, 2009). Not only was the former Yugoslavia multi-ethnic, but each newly formed state in the territory of former Yugoslavia has more-or-less retained this diversity of population. The former Yugoslav republics - now independent states - which were ethnically

\footnotetext{
${ }^{1}$ besicmilos@gmail.com
} 
more homogeneous have proven to be much more effective in making their economic and political transition (e.g. Slovenia), and they are politically and economically significantly more stable compared to the states which included diverse ethnic communities. In the republics with greater ethnic heterogeneity, that is, with population composed of many diverse ethnic communities, the overall post-socialist economic and political progress has been limited to a greater extent. Bosnia and Herzegovina is a typical example of ethnic heterogeneity. It was among most ethnically heterogeneous republics of former Yugoslavia, and it was most heavily affected by the war.

One of the main conclusions, from this perspective, is that in the whole region - beyond the borders of the former Yugoslavia - political processes based on ethnic relations significantly shape ethnic relations in each country. Ethnic relations, for instance, between Serbs and Croats in Bosnia and Herzegovina are not affected only by social, political and other factors within the country, but they also are shaped by the relations between Serbs and Croats in the whole region - particularly by the relations between Croatia and Serbia as independent states. This can apply to all the other relations between ethnic groups in the region.

Montenegro is a somewhat unique case in this regard. Each ethnic minority group in Montenegro has its "mother state." Therefore, the relations among these states, and among the ethnic groups within them, shape the ethnic relations within Montenegro itself. Montenegro is also the only country in the Balkan region in which the majority is relative: less than $50 \%$ of the population is ethnic Montenegrin. Montenegro's political separation from Serbia resulted problems between Montenegrins and Serbs who composed the country's majority together (Malešević \& Uzelac, 2007). Montenegro today is $44.98 \%$ Montenegrin and $28.73 \%$ Serb. In 1991, just after Yugoslavia collapsed, Montenegro remained in a common state with Serbia. At that point, Montenegro's population was $61.9 \%$ Montenegrin and $8.3 \%$ of $\mathrm{Serb}^{2}$. The difference in this ethnic composition of Montenegro stems from the fact that during the process of the country's separation from Serbia, many Montenegrins started to declare themselves ethnic Serbs because of their strong identification with Serbia. It was an expression of their political desire to remain a part of their "mother country", that is, for the connection with the "mother country" not to be broken. Hence, as we demonstrate below, the division between Serbs and Montenegrins is more political than ethnic. In addition to ethnic Montenegrins and Serbs, $8.65 \%$ of the country's residents identify as Bosniaks and $3.31 \%$ as Muslims. It should be stressed that Bosniaks and Muslims are the same ethnic group; there is no division and/or polarization between the two. People who declare themselves Muslim adhere to the traditional ethnic identification which existed in the former Yugoslavia, while people who declare themselves to be Bosniaks are identifying with the post-Yugoslav state of Bosnia and Herzegovina. Over the past two decades, the number of Montenegro residents identifying as Bosniaks has grown steadily at the expense of the number identifying as Muslims, that is, people who used to declare themselves as being Muslims, have started to declare themselves as being Bosniaks. However, it is important to emphasize that - unlike the split between Montenegrin and Serbian identity - there are no political differences between Bosniaks and Muslims or divisions when it comes to identity. Finally, 5\% of Montenegro residents identify as ethni-

${ }^{2}$ Census data. Available at https://www.monstat.org/eng/page.php?id=57\&pageid=57. Last accessed, August 24, 2018. 
cally Albanian, which has remained relatively stable over the years. All other ethnicities make up less than $1 \%$ of the overall population. Therefore, as evidenced, Montenegro is a truly multi-ethnic society, and the issues of ethnicity and ethnic relations are complex. Thus, we can assume that political factors in Montenegro and the whole region strongly influence the inter-ethnic relations within this country, in other words, political factors form and shape inter-ethnic relations within each multi-ethnic state.

The situation in neighboring countries of the former Yugoslavia heavily influenced ethnic relations in Montenegro. In general, ethnic relations were subjected to political elite manipulation (Fearon \& Laitin, 2000). Kaufman (2001) stressed that political leaders easily use collective history, tradition, ideological matrices and myths to shape ethnic relations for their own - usually nationalist - goals (plans). Gagnon (1994) argued that this was the main force driving Yugoslavia's breakdown. However, long-standing inter-ethnic conflicts must have a much deeper historical basis to cause the dissolution of such type of state as Yugoslavia was (Kaplan, 2005). Ethnic relations depend, therefore, on historical legacy and the current political situation/manipulation enforced by the political elite.

\section{Montenegro: ethnic diversity and socio-political framework (context)}

The dissolution of Yugoslavia was initiated and followed by ethnic conflicts. During the breakdown of Yugoslavia, ethnicity became the main source of group identification and the main pillar of the nation-state building process (Bešić, 2001). If ethnicity is the basis of social and political identity in a multi-ethnic society, then the overall social and political stability is highly endangered (Lake \& Rothchild, 1996; Posen, 1993; Colletta \& Cullen, 2000). Ethnic relations in post-war areas depended not only on the traditional processes of ethnic identification and majority/minority status, but also on the overall political situation in the region, since each minority in a particular state was supported by its own mother state which is relatively close to the borders of the state of residence. Montenegro is a unique case in this regard. It was the last country to gain independence after Yugoslavia collapsed. The main reason for this delay was the fact that Montenegrins and Serbs made up the ethnic majority in Montenegro, and both groups strongly identified with their ties to Serbia as the "motherland" in the 1990s. The conflicts in which the Serbs fought against Bosniaks, Croats - and, later, Albanians - all over the former Yugoslavia, had a strong impact on ethnic relations in Montenegro during this period. The actions of the ruling political class led to a disruption of existing inter-ethnic relations in Montenegro (Komar \& Živković, 2016). The ruling political elite and their party - the Democratic Party of Socialists - decided in 1997 to change their position and to separate Montenegro from Serbia (Bieber, 2003). This caused a conflict between Montenegrins and Serbs and the creation of a temporary political coalition among Montenegrins and minority groups (Bosniaks, Albanians and Croats). There is clear evidence that the vast majority of Albanians, Bosniaks and other minorities supported the separation of Montenegro from Serbia at that time, that is, they supported Montenegro's fight for independence (Bešić \& Spasojević, 2018). From the perspective of Bosniaks, Albanians and other ethnic minorities in Montenegro, Serbs represented a threat. In Montenegro, minorities make up more than $20 \%$ of the population, and Serbs perceived those minorities as the 
main factor that brought independence to Montenegro. As a consequence, the Serbs in Montenegro blamed the minority groups for the Serbs' separation from their "mother country" of Serbia. The strained relations between Serbs and minorities in Montenegro were additionally fueled by the ethnic wars across the region. This situation was transferred to inter-ethnic relations in Montenegro, which further deteriorated - because of the role the minorities had (played) in the process of Montenegro's independence. Again, it is important to remember that the conflict between Montenegrins and Serbs was political, not ethnic (Keiichi, 2007). Declaring oneself ethnically Montenegrin equated with the political position of state independence for Montenegro, while declaring as Serbian was a marker of insisting on the continuity of a common state with Serbia (Bešić, 2005). This division of the population led to the fact that the residents of Montenegro who declared themselves to be Montenegrins formed an informal coalition with ethnic minorities and fought together for the separation of Montenegro from Serbia. In 2006, Montenegro formally became an independent state by declaring independence. From that point up to today, the main social and political cleavage in Montenegro has been based on this state independence/ethnic line (Bešić \& Spasojević, 2018).

\section{Hypothesis, data and measurement}

First, we claimed that the division between Montenegrins and Serbs is not ethnic, but political. Therefore, we do not expect to see a high level of ethnic distance between the members of the two major ethnic groups in Montenegro. Second, due to the number of historical and religious influences, we expect to see a high ethnic distance between Serbs and Montenegrins on one side, and Bosniaks and Albanians on the other side. Third, we expect that Serbs will express high distance toward minorities. This is due to the political argument that minorities and their state preferences were crucial for Montenegro's success in gaining state independence. Additionally, due to historical and political reasons, we expect that Serbs would express a particularly strong distance with regards to Albanians. Fourth, we assume that strengthening the political position of Albanians in the region would additionally affect the higher level of ethnic distance between Albanians and other groups, Serbs especially.

Our findings and all measurements and conclusions are based on the traditional widely-used ${ }^{3}$ Bogardus social distance scale. This scale measures the readiness to accept or refuse certain types of relations with the members of other groups. In our case, the referent groups are ethnic groups: Montenegrins, Serbs, Bosniaks and Albanians (i.e. groups which represent more than $1 \%$ of the population of Montenegro). The research was conducted in March 2018, by CEDEM ${ }^{4}$. The research is based on a multi-stage random sampling procedure with a total number of 1000 respondents. Since the sample is representative for the entire population in Montenegro, distribution of ethnicity is in ac-

\footnotetext{
${ }^{3}$ For an overview of the huge number of research studies conducted based on Bogardus scale measurements, see: Wark \& Galliher, 2007.

${ }^{4}$ Center for Democracy and Human Rights - Podgorica. This NGO is regionally recognized as the most prominent research organization in Montenegro. We emphasize that a number of published scientific research papers were published based on their research data. Agency profile: https:// www.cedem.me/
} 
cordance to the overall population distribution. Therefore, in the sample there were $49.7 \%$ of Montenegrins, $28.3 \%$ of Serbs, $14.3 \%$ of Bosniaks/Muslims, $4.6 \%$ of Albanians, and $3.1 \%$ of other minorities.

The measurement of ethnic distance is based on an adjusted Bogardus scale, consisting of nine items/relations. These are: to permanently live in my country; to live in my neighborhood (building or street); to be my co-worker; to be my superior; to teach my children; to visit each other and socialize; to hold a leadership position in my country; to be in a distant relationship through marriage with relatives; and to be in a close relationship through own marriage/or the marriage or children.

In Table 1 all items are presented descriptively, showing the percentage of expressed distance of members of each ethnic group towards the other ethnic groups. In terms of item/relation sensitivity, the hierarchy of distance mostly accords with our expectations. Every following relation implies a closer relation, with two exceptions. First, the items "to be my superior" and "to teach my children" proved to be more sensitive compared to the item "to visit each other." This is probably due to the fact that Montenegro is a traditional society in which visiting and socializing with people who do not belong to one's ethnic group often became a part of everyday life, and it cannot be avoided. Second, the item "to hold a leadership position in my country" proved to be very sensitive. Compared to it, only the items "further relatives" and "close relatives" are more sensitive. This finding represents one of the pieces of evidence that support the thesis that political relations strongly shape ethnic relations in Montenegro.

To test our hypothesis based on these nine items/relations, we created a simple synthetic score of ethnic distance, which is optimized from 0 (no distance) to 1 (high distance). Using the same scale (0 to 1 ), we calculated the distance from each group, and then we calculated the overall score representing the mean value of these scores. Hence, the scores represent the overall distance of the respondents from all the others. The score distribution for the distance from each ethnic group and the total ethnic distance score are presented in Table 2. We measured the greatest distance from Albanians, and the lowest from Montenegrins (the majority).

For precision, we formed set of variables, arranged in the following manner. First, the variables which measure the level of ethnic distance from each group are created as dummy variables and coded as 1 for distance (not accepting the relationship) and 0 for no distance. There are four main ethnic groups, which yields 36 dummy variables (nine for each relationship) measuring ethnic distance. We used these variables to create our main dependent variable (which measures ethnic distance) as explained above. Ethnic identification/belonging as a variable includes the main ethnic groups in Montenegro: Montenegrins, Serbs, Bosniaks/Muslims, Albanians and other. In the regression model, each ethnic category is used as a dummy variable. Gender is used as a dummy variable (male is coded as 1), and age is an interval/continuous variable. Education is set in accordance with the national standard, and this variable has the following values: no education or elementary school; high school education third level; high school education fourth level; higher education; and university education. For the purpose of the regression analysis, each level of education is coded as a dummy variable, and we used the lowest level of education (no education or elementary school) as reference category. Income, in the questionnaire and dataset, was measured 
through a distinctive ordinal scale consisting of 16 levels ranging from "no income" to "more than 1,500EUR". We divided the obtained data into three categories of income (each represents $33 \%$, that is, $1 / 3$ of the criteria). We designated those with income up to 400 EUR as "lower income", those with income between 400 EUR to 700 EUR as "medium income," and those with income over 700 EUR as "high income". Consequently, for the regression analysis, we create three dummy income variables, and "high income" is used as reference category.

\section{Hypotheses testing}

Interethnic distance is presented in Table 3 Based on the total score of ethnic distance, we identified high discrepancies among the groups $[\mathrm{F}(3,965)=22.002, \mathrm{p}<.001]$. Notably, Albanians express the highest level of total ethnic distance, while Montenegrins (the majority) appear to be the most tolerant in relating to others if we analyze total distance score. Albanians distance themselves from Bosniaks and Serbs at approximately the same level $[\mathrm{t}(45)=.701, \mathrm{p}=.487]$, which is an unexpected, but significant finding. The possible explanation is that most of the Albanians in our sample are Catholics (37 out of 46). Another important finding we obtained using the previously mentioned methods and measurements regarding Albanians is that they distance themselves much more from Serbs than from Montenegrins $[t(45)=4.977, \mathrm{p}<.001]$. Serbs express very high distance from Albanians and this is the highest value of distance that we measure. Compared to this distance from Albanians, Serbs distance themselves much less from Bosniaks $[\mathrm{t}(280)=10.858, \mathrm{p}<.001]$, while the distance of Serbs from Montenegrins is very low.

An important finding is that Serbs distance themselves more from each ethnic group than vice versa. The data show that Bosniaks distance themselves much more from Serbs than from Montenegrins [ $t(141)=7.380, \mathrm{p}<.001]$, and we found the same with Albanians' distance from Serbs and Montenegrins. Furthermore, Bosniaks express much lower distance from Albanians than vice versa. Finally, Montenegrins (the majority) express the smallest value of total ethnic distance compared to other ethnicities. This finding stems from the fact that Montenegrins express a low distance from Serbs. Still, both Albanians and Bosniaks are much less acceptable for Montenegrins than vice versa (i.e. Montenegrins express higher distance from minorities than vice versa).

Returning to the fact that we measured the lowest level of inter-ethnic distance between Montenegrins and Serbs, Table 1 shows that the most sensitive item in measuring inter-ethnic distance between Serbs and Montenegrins is "to hold a leadership position in my country." This item is explicitly political, and as we have stressed, the issue of state independence of Montenegro is the basis for the distance between Serbs and Montenegrins. The data shows that $13.2 \%$ of Montenegrins would not accept a Serb holding a leadership position in the country, while the respective value for Serbs toward Montenegrins is $12.5 \%$. All the other distance values between Serbs and Montenegrins are much lower, almost minimal. This is simple and strong evidence that the division between Montenegrins and Serbs is political, not ethnic. This fact suggests the possible conclusion that political factors play an important role in the overall ethnic distance and in ethnic relations in Montenegro in general. 
We utilize an OLS regression analysis to estimate the effect of ethnicity on ethnic distance in a multivariate environment. In Table 4, we present unstandardized regression coefficients in four models; Each model represents the distance from one ethnic category. In Model 1, the dependent variable is the ethnic distance from Montenegrins; in Model 2, the dependent variable is the ethnic distance from Serbs; in Model 3, the dependent variable is the ethnic distance from Bosniaks; and in Model4, the dependent variable is the ethnic distance from Albanians.

The obtained data justifies the introduction of control variables into the models. University education is a strong negative predictor of the distance from each ethnic group, apart from Montenegrins (as the majority). This suggests that citizens who completed university education would probably express less distance from members of other ethnicities compared to those with the lowest level of education. In estimating the distance expressed by Serbs and Bosniaks, we also found significant differences between people who finished the fourth level of high school education and higher education, compared to people with the lowest level of education. It seems that these two categories are directly opposed. It appears that there is not much difference between people who finished the third level of high school and people with the lowest level of education. Only with the distance from Serbs did we find any difference in this regard.

Estimating the distance from Montenegrins and Serbs, low income is a strong positive predictor of ethnic distance. In each model, we found no difference between medium and high income, which suggests that income could be a negative predictor only when it is particularly low. When the income reaches some "reasonable sum", a further increase in income would not significantly decrease the level of ethnic distance. Belonging to each ethnicity is a strong predictor of ethnic distance toward other ethnic groups. In this situation, even relatively small differences are statistically significant. After introducing control variables, Serbs are much more intolerant toward Albanians and Bosniaks than vice versa. On the other hand, Albanians distance themselves more from Bosniaks than from Montenegrins, but it is interesting that Albanians distance themselves more from Bosniaks than from Serbs, as we already noted in the descriptive analysis. With Bosniaks, the level of distance from Serbs and Albanians is almost equal, which is an interesting discovery. The main finding is that minorities (Albanians and Bosniaks) distance themselves from the Montenegrin majority less than vice versa. This majority/minority relationship shows that the majority expresses higher distance from minorities than vice versa. It is very important that minorities distance themselves much more from Serbs than from Montenegrins. Keeping in mind that the difference between Serbs and Montenegrins is political, not ethnic, this data shows the political aspect of distance from Serbs.

Additionally, the effect of region on ethnic distance is evident. People who live in the north tend to distance themselves more from other ethnicities compared to people who live by the sea. The only exception is the distance expressed by Montenegrins (the majority). Controlling for the entire set of variables, including ethnicity, living in the north - as opposed living by the sea - increases the distance from Albanians for .190, Bosniaks for .143 , and Serbs for .040. Furthermore, there is no significant difference in each model between the central part of Montenegro and the one by the sea, suggesting that the north is specific compared to the other two regions. 


\section{Conclusion}

Ethnic relations in a multi-ethnic society are deeply rooted in historical factors that shape these ethnic relationships. Cultural and religious differences play a significant role as well. Additionally, "strong" structural variables, such as education and income, traditionally are significant predictors of ethic distance and relations. In this paper, we provide argumentation and empirical evidence that political factors also greatly influence ethnic relations. Each state which arose in the wake of Yugoslavia's collapse is based on a referent ethnic group and national identity as the main collective political actor in the state formation process. Consequently, ethnic relations in these countries are very much about the political factors and current political situation.

Montenegro gained its independence only twelve years ago. The struggle for independence was very complex and lasted a long amount of time because the integrity of Montenegro as an independent state was being built on a complex national identity. The national identity of Montenegro has always resided on the conflict between Montenegrin vs. Serb identity. The conflict between the two was never ethnic; it was always political. It was about the construction of an ethno-political identity. This was the primary discord factor during the recent process of detaching Montenegro from Serbia, and it remains so today. However, we note the significance of the issue of 'agencies' (Giddens, 1979) regarding the recent political constellation, which resulted in the independence of Montenegro. The ruling political elite leader (Milo Đukanović) has played a significant role over the past three decades. The same political elite, which came into power during the socialist period, became the strongest supporter of Serbian identity in Montenegro during 1990s. Then, the same elite unexpectedly switched sides, assuming the attitude against Serbia, leading the whole society towards independence. Therefore, we insist that the clash between Serbs and Montenegrins is not ethnic; but almost exclusively political, which we have demonstrated through data presented in this paper.

However, these political processes did not only shape the relations between Montenegrins and Serbs. As we have shown, these factors played a significant role in shaping the ethnic relations among all groups. Besides the strong historical factors which traditionally affect ethnic relations between Albanians and Serbs, political factors over the past decade particularly diminished the relations between these two ethnic groups. The deterioration of relations between Serbs and Albanians started much earlier and they've been heavily damaged at the end of the last century. However, over the past couple years the relations between the two ethnic groups have been complicated by the so-called process of "normalization" which has been the focus of thorny political negotiations between Belgrade and Priština, mediated by the international community. Furthermore, exacerbating the political identity clash between Serbs and Montenegrins, Albanians in Montenegro were strong supporters of Montenegro independence, and the Serbs perceive the Albanians 'enemies'. According to our research, these political factors have significantly deepened the high ethnic distance between Albanians and Serbs.

We substantiate our claim about the importance of political factors, or the influence that political factors have on ethnic relations, with empirical evidence that clearly indicates that the level of ethnic distance between Albanians and Bosniaks on the one hand, and Montenegrins on the other, is much lower than the level of ethnic distance 
that exists between minorities and Serbs. This is due to Albanians and Bosniaks having strongly supported the independence of Montenegro. They thus became the allies of Montenegrins and started a clash against the Serbs. Accordingly, for the same reasons, Serbs perceived Albanians and Bosniaks as the enemies of their "legitimate" national interest to stay united with 'their' mother country of Serbia. This explains the high level of distance between Serbs and Bosniaks, as well as the strongest distance from Albanians. However, it also is important to remember - when considering the high distance of Serbs from Bosniaks and vice versa - that for years an ethnic war raged between the two ethnic groups in Bosnia. Even today, there is an open political conflict in Bosnia between the Serbian entity (Republic of Srpska) and the Bosniak-dominated Federation of Bosnia and Herzegovina. Thus, it can be argued that ethnic relations are highly dependent on political factors. The high level of ethnic distance we identified in this research contributes to this thesis. 
Милош љ. Бешић 1

Универзитет у Београду

Факултет политичких наука

Београд (Србија)

\title{
ЕТНИЧКИ ОДНОСИ У ЦРНОЈ ГОРИ ГОРИ 12 ГОДИНА НАКОН СТИЦАњА НЕЗАВИСНОСТИ
}

\author{
(Превоg In Extenso)
}

Сажетак: Овај рад представља анализу међуетничких односа у Црној Гори 12 година након што је ова сада већ бивша чланица Југославије стекла своју независност. Етничке односе анализирали смо користећи методу мерења етничке дистанце. Рад се ослања на емпиријске податке који указују на ниво међуетничког и укупног етничког дистанцирања. Ово истраживање, односно сва мерења спроведена током овог истраживања, заснивају се на традиционалној Богардусовој скали социјалне дистанце. Истраживачки циљ ове анализе, осим дескриптивних задатака које има, јесте и то да покаже ефекат политичких фактора на етничко дистанцирање. Основну хипотезу смо тестирали користећи OLS регресиону методу (регресиона анализа). Подаци које смо добили указују на веома висок ниво међуетничке дистанце између Срба, с једне стране, и националних мањина, с друге стране. Такође смо утврдили да постоји веома низак ниво етничке дистанце између Црногораца и Срба, што потврђује тезу да је раздор између њих, односно разлика која постоји више политичке него етничке природе.

Кључне речи: Црна Гора, етнички односи, етничке дистанце, Богардусова скала, OLS регресиона анализа

\section{Увод}

У послератној Југославији, питање националности било је једно од најважнијих у процесу обликовања друштвеног и политичког живота. Није претерано рећи да су неки од главних фактора који су допринели распаду Југославије - управо питања националности, идентификације и етнички односи (Sekulić, Massey, Hodson; 2006). Нација је постала кључни колективни актер у процесу изграђивања националних држава, и то је процес који је започео одмах после распада Југославије (Brubaker, 1996; Bešić, 2001). Свака новонастала држава се засновала на националној мобилизацији, а у једној мултиетничкој држави, каква је у том тренутку била Југославија, то је за последицу имало међуетничке ратове (Denitch,1996). Због свега тога, односи између

${ }^{1}$ besicmilos@gmail.com 
етничких група које су сачињавале бившу Југославију, били су, а и још увек су, нарушени (O’loughlin \& Tuathail, 2009). Треба истаћи и то да није само бивша Југославија била мултиетничка држава; ту разноликост у саставу становништва, у мањој или већој мери, задржале су и све нове државе настале на територији бивше Југославије после њеног распада. Оне државе, из састава бивше Југославије, а које су данас самосталне, односно - независне државе, које су биле етнички мање разнолике много су лакше прошле кроз процес транзиције, и данас су у значајно већој мери политички и економски стабилне него што је то случај са државама које су у свом саставу имале више различитих етничких заједница. Укупан постсоцијалистички економски и политички процес био је у великој мери ограничен у оним републикама у којима је становништво било разнолико, односно састављено од већег броја различитих етничких група. Босна и Херцеговина типичан су пример етничке разноликости. Она је спадала у једну од етнички најхетерогенијих република бивше Југославије, а управо је она била највише страдала у рату.

Намеће се закључак, из ове перспективе посматрано, да на нивоу читавог региона - изван граница бивше Југославије - оно што у значајној мери обликује етничке односе у свакој држави појединачно јесу управо политички процеси засновани на тим етничким односима. На пример, на односе између Срба и Хрвата у Босни и Херцеговини не делују само друштвени, политички и разни други фактори у оквиру ове државе (БиХ), већ и односи између ове две етничке скупине у целом региону, а посебно они односи између Србије и Хрватске као две независне државе. Ово важи и за све друге односе који постоје између етничких група у региону.

Црна Гора у овом погледу представља јединствен случај. Свака национална мањина која је сачињава има своју матичну државу. Због тога су односи између ових држава, и између референтних етничких група обликовали односе у оквиру саме Црне Горе. Такође, Црна Гора је једина држава на Балкану у којој је већина релативна, дакле, мање од 50\% становништва се изјаснило као Црногорци. Политичко одвајање Црне Горе од Србије проузроковало је раздоре између Срба и Црногораца који су тада заједно чинили већину становништва Црне Горе (Malešević \& Uzelac, 2007). Данас у Црној Гори живи 44,98\% Црногораца и 28,73\% Срба. Године 1991, одмах после распада Југославије, Црна Гора је остала у заједничкој држави са Србијом. У том тренутку, становништво Црне Горе сачињавало је 61,9\% Црногораца и 8,3\% Срба ${ }^{2}$. Ове разлике у етничком саставу Црне Горе произлазе из чињенице да су се, током процеса одвајања Црне Горе од Србије, многи Црногорци почели изјашњавати као Срби, услед снажног осећаја политичке идентификације са Србијом. То је био њихов начин да изразе своју политичку тежњу да остану заједно у „матичној држави“, односно начин да се веза између њих и „матичне државе” не раскине. Дакле, разлике које постоје између Срба и Црногораца нису етничке, већ политичке природе, као што ћемо и показати у овој анализи. Осим Црногораца и Срба, у Црној Гори данас живи 8,65\% Бошњака и 3,31\% Муслимана. Треба нагласити су Бошњаци и Муслимани иста етничка група, односно да међу њима не постоје разлике нити поларизација. Они који су се изјаснили као Муслимани, идентификују се са традиционалном етничком групом која је постојала у бившој Југославији, док се

2 Подаци пописа. Доступно на страници: https://www.monstat.org/eng/page.php?id=57 \&page$\mathrm{id}=57$. последња измена (приступ), 24. август 2018. 
они који су се изјаснили као Бошњаци идентификовали са државом Босном и Херцеговином, која је настала после распада Југославије. Током последње две деценије, број оних становника Црне Горе који се изјашњавају као Бошњаци расте, док се истовремено број оних који се изјашњавају као Муслимани смањује тј.они који су се раније декларисали као Муслимани, сада се, све више декларишу као Бошњаци. Важно нагласити да између Бошњака и Муслимана не постоје разлике и раздори, као ни поделе кад је њихов идентитет у питању, као што је случај између Црногораца и Срба. Осим наведених, 5\% становништва Црне Горе чине Албанци, и овај проценат се није битно мењао током претходних година. Сви остали народи, односно националне мањине, које живе у Црној Гори, појединачно чине мање од $1 \%$ укупног броја становника. Дакле, као што се може видети из свих приложених података, Црна Гора се заиста може назвати мултиетничком државом, у којој су проблеми националности, као и односи међу националним мањинама, веома комплексни. На основу свега тога можемо претпоставити да су управо политички фактори у Црној Гори, али и у целом региону, оно од чега у доброј мери зависе међу-етнички односи унутар саме државе, другим речима политички фактори у великој мери формирају и обликују међуетничке односе унутар сваке мултиетничке државе.

Међуетнички односи који постоје унутар других држава бивше Југославије, имали су снажан утицај на међуетничке односе у Црној Гори. Уопштено говорећи, етнички односи били су подређени манипулацијама политичке елите (Fearon \& Laitin, 2000). Кауфман (Kaufman, 2001) наглашава да политички лидери с лакоћом користе заједничку историју, традицију, идеолошке матрице и митове како би обликовали етничке односе, како би остварили своје, најчешће националистичке, циљеве (планове). Гагнон (Gagnon, 1994) тврди да је управо ово био покретач, односно главни узрок распада Југославије. Ипак, треба нагласити и то да дугогодишњи међуетнички сукоби, сами по себи, не би могли бити узрок распада једне државе (каква је била Југославија), а да нису засновани на неким много дубљим историјским расколима (Kaplan, 2005). Етнички односи зависе, дакле, од историјског наслеђа, али и од тренутне политичке ситуације, односно манипулације коју спроводи политичка елита.

\section{Црна Гора: етничка разноликост и друштвено-политички оквир (контекст)}

Распад Југославије био је проузрокован и праћен етничким сукобима. Током распада Југославије, националност је била не само основа групне идентификације, него и темељ на којем су започети процеси изградње државе (Bešić, 2001). Ако је националност оно на чему се заснивају друштвени и политички идентитет једног мултиетничког друштва, онда су друштвена и политичка стабилност у тој држави у великој мери угрожени (Lake \& Rothchild, 1996; Posen, 1993; Colletta \& Cullen, 2000). Односи између етничких група које су после распада Југославије остале да живе на истој територији, зависили су не само од традиционалних процеса идентификације етничке групе и статуса мањине односно већине, него и од опште политичке ситуације у региону - која је била прилично сложена, имајући у виду да је свака национална мањина у једној држави имала ослонац у својој матичној држави, која је при том и територијално близу 
државних граница. Случај Црне Горе је свакако јединствен. После распада Југославије Црна Гора је последња стекла своју независност. Главни разлог за ово „одлагање” проглашења независности била је управо чињеница да већину становништва Црне Горе чине управо Црногорци и Срби, те да су обе етничке групе осећале веома јаку повезаност са Србијом као својом матичном државом током деведесетих година прошлог века. Конфликти у којима су се Срби борили против Бошњака, Хрвата, а касније и Албанаца - на територији целе некадашње Југославије, имали су изузетно јак утицај и на етничке односе у Црној Гори током овог периода. Поступци владајуће политичке класе проузроковали су нарушавање постојећих етничких односа у Црној Гори (Кomar $\&$ Živković, 2016). Током 1997. године владајућа политичка елита оличена у владајућој партији (Демократска партија социјалиста) одлучила је да промени свој политички курс и да одвоје Црну Гору од Србије (Bieber, 2003). Овакво политичко деловање проузроковало је конфликт између Црногораца и Срба, те је довело до формирања привремене политичке коалиције између Црногораца и националних мањина (Бошњака, Албанаца и Хрвата). Постоје несумњиви подаци који указују да је велика већина Албанаца, Бошњака и других етничких група, националних мањина у Црној Гори, подржавала одвајање Црне Горе од Србије у том тренутку, односно подржавали су Црну Гору у њеној борби за независност (Bešić \& Spasojević, 2018). Срби су, из перспективе Бошњака, Албанаца и других националних мањина, представљали претњу. Више од $20 \%$ становништва Црне Горе чине управо националне мањине, а Срби су представнике мањина доживљавали као један од кључних фактора који је Црној Гори донео независност. Последично, Срби који су живели у Црној Гори, кривили су припаднике националних мањина за њихово одвајање од „матичне државе” Србије. Ови, већ прилично лоши, односи између Срба и националних мањина у Црној Гори, били су додатно нарушавани ратовима који су беснели у целом региону. То се пренело и на односе између самих етничких група у Црној Гори, а који су се прогресивно погоршавали - због улоге коју су националне мањине имале (одиграле) у борби за независност Црне Горе. При том наглашавамо да је сукоб између Црногораца и Срба искључиво политичке, а не етничке природе (Keiichi, 2007). Они грађани Црне Горе који су се декларисали као Црногорци, односно припадници ове етничке групе, чинили су то из политичких разлога, сматрајући да је независност Црне Горе оправдано и једино исправно решење, док су они који су се декларисали као Срби, тим поступком показали приврженост Србији и жељу да остану у заједничкој држави (Bešić, 2005). Оваква подела становништва, довела је до тога да су они становници Црне Горе који су се декларисали као Црногорци формирали неформалну коалицију са припадницима националних мањина, а затим се заједно изборили за издвајање Црне Горе од Србије. Током 2006. године Црна Гора је и формално постала самостална држава проглашењем своје независности. Од тог тренутка, па све до данас, проглашење независности Црне Горе и повлачење етничких граница, представља кључну линију друштвених и политичких расцепа у Црној Гори (Bešić \& Spasojević, 2018).

\section{Хипотезе, подаци и мерења}

На самом почетку тврдили смо да је раздор између Црногораца и Срба искључиво политичке, а не етничке природе. Управо због тога не очекујемо висок 
ниво етничке дистанце између припадника две највеће етничке групе у Црној Гори. Друго, ослањајући се на историјске и религијске разлике очекујемо високу етничку дистанцу између Срба и Црногораца, с једне стране, и Бошњака и Албанаца, с друге. Треће, очекујемо да ће Срби исказивати високу етничку дистанцу према свим националним мањинама. Ова очекивања заснована су на чињеници да је улога коју су националне мањине имале у борби за независност Црне Горе била пресудна, тј. да је управо захваљујући њима Црна Гора успела да оствари независност. Осим тога, услед многобројних историјских и политичких разлика, очекујемо да ће Срби показати високу етничку дистанцу према Албанцима. Четврто, претпостављамо да ће јачање политичке позиције у региону кад су Албанци у питању, утицати и на ниво етничке дистанце између Албанаца и других етничких група, односно да ће ниво етничке дистанце бити много виши, посебно према Србима.

Ова анализа, односно сва мерења и закључци до којих смо током овог истраживања дошли, заснивају се на традиционалној, веома често коришћеној, ${ }^{3}$ Богардусовој скали социјалне дистанце. Ова скала мери степен спремности да се прихвати или не прихвати одређени тип односа са припадницима других група. У нашем случају, референтне групе су етничке групе: Црногорци, Срби, Бошњаци и Албанци (односно оне етничке групе чији број тј. проценат припадника чини више од $1 \%$ од укупног броја становника Црне Горе). Истраживање је спроведено током марта 2018. године, од стране CEDEM-а ${ }^{4}$. Истраживање се заснива на вишестепеној процедури узорковања, са случајним избором испитаника, у којој је учествовало 1000 испитаника. Узорак је репрезентативан за целокупну пунолетну популацију у Црној Гори, а етничка структура у узорку је у складу са реалном структуром становништва према послењем попису становништва. Дакле, у истраживању је учествовало 49,7\% Црногораца, 28,3\% Срба, 14,3\% Бошњака/Муслимана, 4,6\% Албанаца и $3,1 \%$ осталих.

За мерење етничке дистанце користили смо проширену Богардусову скалу састављену од девет ајтема/односа. То су: да живи у мојој држави; да станује у мом суседству (у истој згради или улици); да ми буде сарадник на послу; да ми буде претпостављени на послу; да буде васпитач мојој деци; да се дружим и посећујем са њим/ њом; да има руководећи положај у мојој држави; да будемо у даљем сродству путем брака са рођацима; да будемо у блиском сродству путем властитог брака или деце.

У Табели 1. дати су дескриптивно сви ајтеми/односи, који показују ниво етничке дистанце у процентима а коју су припадници сваке поједине етничке групе исказали према припадницима других етничких група. Када је реч о осетљивости ајтема/односа, хијерархија измерене дистанце се скоро у потпуности поклапа са очекивањима. Свака следећа релација имплицира ближи однос уз два изузетка. Прво, ајтеми „да ми буде претпостављени на послу” и „да буде учитељ/васпитач мојој деци” показали су већи степен осетљивости, у односу на степен осетљивости

3 За преглед великог броја истраживања спроведених на основу мерења Богардусовом скалом, види: Wark \& Galliher, 2007.

${ }^{4}$ Центар за демократију и људска права - Подгорица. Ова НВО је регионално призната као најистакнутија истраживачка организација у Црној Гори. Напомињемо да је значајан број научних радова објављен на основу података истраживања ове организације. Више информација о самој агенцији налази се на страници: https://www.cedem.me/ 
који смо измерили код ајтема „посећујемо једни друге”. Разлог за овакве резултате треба тражити у чињеници да су посећивање и дружење са припадницима других етничких група постали саставни део свакодневног живота једног традиционалног друштва као што је црногорско, и као такав, овај однос не може бити избегнут. Друго, код ајтема „да има руководећи положај у мојој држави” утврдили смо веома велики степен осетљивости. Само су два ајтема показала већи степен осетљивости у поређењу са њим, а то су ајтеми „даљи рођаци” и „блиски рођаци”. Управо овај податак представља један од доказа који иде у прилог нашој тези да етнички односи у Црној Гори зависе доминантно од политичких односа.

Да бисмо тестирали нашу хипотезу посредством ових девет ајтема/односа, формирали смо једноставан синтетички скор етничке дистанце, у којем 0 означава (однос) „без дистанце”, а 1 „висок ниво дистанце”. Исту скалу (од 0 до 1) користили смо за мерење дистанце пема свим групама, а затим смо помоћу средње вредности (аритметичке средине) формирали укупан скор. Дакле, скорови представљају укупну дистанцу коју су испитаници који припадају једној етничкој групи показали према припадницима других етничких група. Дистрибуција мерене дистанце према свакој етничкој групи као и скор укупне етничке дистанце приказани су у Табели 2. Највећи скор измерили смо кад је у питању дистанца према Албанцима, а најмањи према Црногорцима који чине већину у узорку.

Ради прецизније анализе формирали смо сет варијабли, које смо организовали на следећи начин. Прво, варијабле које мере ниво етничке дистанце према свакој групи су креиране као дами варијабле, у којима 1 означава дистанцу (не прихвата однос, дакле дистанца постоји), док 0 означава да нема дистанце. У овој анализи учествовали су припадници четири етничке групе, дакле, као резултат поређења односа између њих добили смо укупно 36 дами варијабли за мерење етничке дистанце (девет за сваки однос). Ове варијабле користимо да креирамо главну зависну варијаблу која мери етничку дистанцу, као што смо већ објаснили у претходном делу текста. Етничка идентификација односно осећај припадности као варијабла, укључује припаднике свих великих етничких група у Црној Гори: Црногорце, Србе, Босанце/Муслимане, Албанце и остале. У регресионом моделу, припадност свакој етничкој категорији се користи као дами варијабла. Пол се користи као дами варијабла (припадници мушког пола су кодирани као 1), док се старост испитаника користи као интервална варијабла. Образовање је приказано у складу са националним стандардом, стога ова варијабла има неколико вредности: без образовања или само основно образовање; средње образовање трећег степена; средње образовање четвртог степена; више образовање; високо образовање (универзитет). За потребе регресионе анализе, сваки степен образовања је кодиран као дами варијабла, а као референтну категорију у анализи користили смо најнижи степен образовања („без образовања или завршена само основна школа”). Приходи су у истраживању мерени посредством уобичајене дистинктивне ординалне скале која садржи 16 категорија у распону од „без прихода” до „зарађујем више од 1.500 евра”. Податке добијене током истраживања, који се тичу висине прихода, поделили смо у три категорије (свака чини 33\%, односно $1 / 3$ критеријума) Прву групу прихода означили смо као „мали (ниски) приходи”, у коју спадају приходи до 400 евра, другу групу прихода смо означили као „приходи средње висине”, у коју спадају приходи између 
400 и 700 евра, док смо трећу групу означили као „високи приходи”, а у коју смо сврстали све приходе изнад 700 евра. За потребе регресионе анализе, формирали смо три дами варијабле којима смо приказали податке који се односе на висину прихода испитаника, као референтна категорија коришћена је група означена као „високи приходи”.

\section{Тестирање хипотезе}

Међуетничка дистанца је приказана у Табели 3. На основу укупног скора етничке дистанце, идентификовали смо веома висок ниво разлика између група $[\mathrm{F}(3,965)=22.002, \mathrm{p}<.001]$. Подаци до којих смо дошли указују да Албанци исказују највећи степен укупне етничке дистанце, док Црногорци показују најнижи степен укупног дистанцирања. Другим речима, могли бисмо рећи да су Црногорци најтолерантнији кад су у питању односи према другим народима односно етничким групама. Албанци показују приближно исти степен дистанце према Бошњацима и према Србима [t(45)=.701, p=.487], што можемо окаректерисати као веома неочекиван, али и значајан налаз. Једно од могућих објашњења свакако би се могло потражити у чињеници да су Албанци који су учествовали у нашем истраживању били претежно католичке вероисповести (37 од 46). Подаци, такође, указују да се Албанци у већој мери дистанцирају од Срба него од Црногораца $[\mathrm{t}(45)=4.977, \mathrm{p}<.001]$, и ово је веома важан податак до ког смо дошли у овом истраживању, користећи поменуте методе односно мерења. Срби показују веома висок ниво дистанцирања према Албанцима; и управо је ова вредност етничке дистанце - највећа измерена вредност у овом истраживању. Дистанца коју показују Срби према Бошњацима, нешто је нижа од оне коју показују према Албанцима $[\mathrm{t}(280)=10.858, \mathrm{p}<.001]$, док је дистанца коју Срби показују према Црногорцима веома ниска.

Значајан податак је да је дистанца коју показују Срби према етничким групама, виша од оне дистанце коју показују други народи односно припадници других етничких група према Србима. Подаци указују да је дистанца коју Бошњаци показују према Србима много већа од оне дистанце коју показују према Црногорцима $[\mathrm{t}(141)=7.380, \mathrm{p}<.001]$, приближно исти ниво дистанце измерили смо и код Албанаца када су у питању односи према Србима, као и према Црногорцима. Бошњаци показују нижи ниво дистанце према Албанцима, него што је то случај у обрнутој ситуацији, односно када говоримо о дистанци коју показују Албанци према Бошњацима. Најнижи степен укупне етничке дистанце коју једна етничка група показује, у поређењу са свим другим тестираним етничким групама, измерили смо управо код Црногораца (већина популације Црне Горе). Овакви резултати последица су веома мале дистанце коју су Црногорци показали према Србима. Ипак, треба нагласити да ни Албанци ни Бошњаци нису толико прихватљиви Црногорцима, барем не у истој мери као што је то случај у обрнутој ситуацији; дакле, Црногорци су показали већи степен етничке дистанце према националним мањинама, од оног који су показале мањине према Црногорцима као већини.

Вратимо се на чињеницу да смо најнижи ниво међуетничке дистанце измерили између Црногораца и Срба. Табела 1 приказује да је најосетљивији ајтем мерења 
међуетничке дистанце између Срба и Црногораца: „да има руководећи положај у мојој држави”. Овај ајтем је јасно и недвосмислено политички, што значи да, управо као што смо и истицали, разлог за постојање дистанце између Црнорогаца и Срба треба тражити у захтеву Црне Горе да се одвоји од Србије. Подаци указују да 13,2\% Црногораца не би прихватило ситуацију у којој се Србин налази на водећој политичкој позицији у држави; док су респективне вредности измерене код Срба према Црногорцима 12,5\%. Све остале вредности етничке дистанце које су измерене између Срба и Црногораца су знатно ниже, готово минималне. Ово је једноставан и веома чврст доказ у прилог тези да је раздор који постоји између Срба и Црногораца искључиво политички, а не етнички. Управо нас ова чињеница наводи на закључак да су политички фактори веома важни за формирање и обликовање етничких односа, као и за ниво укупне етничке дистанце међу свим етничким групама у Црној Гори.

Коначно, користили смо OLS регресиону анализу да проценимо утицај националности на етничку дистанцу у мултиваријантном окружењу. Табела 4 приказује четири модела који садрже нестандардизоване регресионе коефицијенте. Сваки модел представља дистанцирање према једној етничкој категорији. У моделу 1, зависна варијабла је етничка дистанца према Црногорцима; у моделу 2, зависна варијабла је етничка дистанца према Србима; у моделу 3, зависна варијабла је дистанца према Бошњацима; и у моделу 4, зависну варијаблу чини етничка дистанца према Албанцима.

Подаци које смо прикупили током овог истраживања, оправдали су увођење контролних варијабли у моделе. Универзитетско образовање је веома јак негативни предиктор дистанце коју показује свака етничка група према другим етничким групама, осим код Црногораца (као већине). То значи да ће они грађани који имају веома висок степен образовања (универзитетско образовање), највероватније, показати најмањи степен дистанце према грађанима који припадају другим етничким групама, у поређењу са дистанцом коју ће исказати они са веома ниским образовањем (или без образовања). Процењујући дистанцу коју показују Срби и Бошњаци, приметили смо значајне разлике између оних који су завршили средњу школу четвртог степена и оних који имају веома високо образовање, с једне стране, те оних који имају образовање неког нижег степена, с друге стране; могли бисмо рећи да су ове две категорије директно супротне једна другој. Намеће се и закључак да нема великих разлика између оних који имају образовање трећег степена, и оних који имају само основно образовање. У овом погледу једини изузетак је дистанца према Србима.

Мерећи дистанцу према Црногорцима и Србима, ниска примања представљају веома значајан позитивни предиктор етничке дистанце. Ни у једном од четири модела нисмо пронашли разлике између средњих и високих зарада, што значи да зарада може бити негативан предиктор само у случају ако је прилично ниска. Кад зарада једном достигне „разуман износ”, промене навише неће битно утицати на ниво етничке дистанце. Припадност свакој етничкој групи представља веома снажан предиктор етничке дистанце према другим етничким групама. У оваквој ситуацији, чак су и релативно мале разлике статистички значајне. Увођењем контролних варијабли показало се да су Срби много мање толерантни према Албанци- 
ма и Бошњацима него Албанци и Бошњаци пема Србима. С друге стране, Албанци се више дистанцирају од Бошњака, него од Црногораца; а врло је интересантна чињеница да се Албанци више дистанцирају од Бошнака него од Срба, као што смо већ приметили у дескриптивној анализи. Кад су у питању Бошњаци, односно дистанца коју показују, примећујемо да нема велике разлике између дистанце према Србима и оне према Албанцима, што свакако представља једно интересантно откриће. Ипак, најзначајнији податак до којег смо дошли користећи регресиону анализу је онај који указује да се националне мањине (Албанци и Бошњаци) много мање дистанцирају према Црногорцима него што је то обрнуто. Овај однос већина/ мањина показује да већина становништва исказује већу дистанцу у односу према мањинама, него обрнуто. Веома је важно и то што се мањине дистанцирају много више од Срба него од Црногораца. Имајући на уму чињеницу да је разлика између Срба и Црногораца политичке а не етничке природе, можемо закључити да ови подаци указују на политичке аспекте етничког дистанцирања.

На крају, треба поменути и то да на етничке односе веома велики утицај има и сама територија односно географски положај. Они који живе на северу показују већи степен дистанце према другим етничким групама, у поређењу са онима који живе поред мора. Једини изузетак је дистанца коју показују Црногорци, као већина становништва. Контролишући цео сет варијабли, укључујући и националност, они који живе на северу насупрот оних који живе на приморју, повећава дистанцу према Албанцима за 0.19, Бошњацима за 0.143, и према Србима за 0.04. Ни један од четири модела није показао битне разлике између централног дела Црне Горе и приморја, што наводи на закључак да је север Црне Горе веома специфичан, у поређењу с друга два региона.

\section{Закључак}

Етнички односи у мултиетничком друштву зависе од бројних историјских фактора, који у великој мери обликују те односе. Важну улогу свакако имају културне и религијске разлике, а томе треба додати и утицај снажних структуралних варијабли, као што су образовање и приходи, а који се традиционално сматрају важним факторима етничког дистанцирања. У овом раду ми показујемо и аргументујемо, да и политички фактори могу бити веома значајни када су у питању етнички односи. Свака држава која је настала на територији бивше Југославије после њеног распада, изграђена је на референтној етничкој групи и националном идентитету као главном политичком актеру у процесу формирања држава. Као последица тога етнички односи у овим земљама у великој мери зависе од политичких фактора и тренутне политичке ситуације.

Црна Гора је стекла своју независност тек пре 12 година. Борба за независност била је веома комплексна и трајала је дуго због тога што се интегритет Црне Горе као независне државе градио на комплексном националном идентитету. Државни идентитет Црне Горе, историјски гледано, одувек је почивао на кофликту између Црногораца и Срба. Важно је нагласити да конфликт између њих никада није био етнички, него политички; а тицао се начина на који је конструисан етничко-политички идентитет. Ово је био примарни фактор раздора у, не тако давном, процесу 
одвајања Црне Горе од Србије, а тако је и данас. Треба, међутим, имати у виду значај "агентуре“ (Giddens, 1979) када је реч о тренутној политичкој констелацији која је резултирала независношћу Црне Горе. Неспорни политички лидер и предводник владајуће политичке елите (Мило Ђукановић) имао је веома значајну улогу током претходне три децениије. Дакле, иста та политичка елита, која је дошла на власт током социјалистичког периода, пружала је највећу подршку српском идентитету у Црној Гори током деведесетих; затим је, сасвим неочекивано, променила страну, и заузимајући став против Србије, повела црногорско друштво у борбу за независност. Управо због тога истичемо да раздор између Срба и Црногораца није етнички, већ готово искључиво политички, а што смо показали и подацима изложеним у овом раду.

Свакако, треба нагласити и то да ови политички процеси нису обликовали само односе између Црногораца и Срба. Као што смо показали, ови процеси имали су веома важну улогу и за обликовање етничких односа између свих етничких група. Поред снажних историјских фактора који традиционално утичу на односе између Албанаца и Срба, ови односи обликовани су и бројним политичким факторима скоријег датума, и то у негативном смеру. Раздор између Срба и Албанаца почео је много раније, а њихови односи трајно су нарушени крајем прошлог века. Током претходних година односи између ове две етничке групе додатно су закомпликовани такозваним процесом „нормализације” који је био у фокусу веома тешких политичких преговора између Београда и Приштине, у којима се као посредник појављује међународна заједница. Свему томе треба додати и чињеницу да Срби у Црној Гори у Албанцима „виде” непријатеље, јер су у борби за независност Црне Горе, односно за њено одвајање од Србије, Албанци веома снажно подржавали независност, чиме су појачали, ионако велики политички раздор који је постојао. Према подацима из истраживања које смо спровели, ови политички фактори додатно су продубили етничку дистанцу између Албанаца и Срба.

Нашу тврдњу о значају политичких фактора, односно о утицају који политички фактори имају на етничке односе, поткрепили смо емпиријским доказима који јасно указују на то да је ниво етничке дистанце између Албанаца и Бошњака с једне, и Црногораца с друге стране, много нижи од нивоа етничке дистанце која постоји између мањина и Срба. Разлог за овакву етничку дистанцу је чињеница да су Албанци и Бошњаци стали на страну Црне Горе у њеној борби за независност, и снажно је у томе подржавали. Тиме су постали савезници Црногораца, а уједно су и отворили фронт према Србима. Дакле, националне мањине су стале на страну оних Црногораца који су се залагали за независност Црне Горе, док су, истовремено из истог разлога, постали непријатељи Србима који су сматрали да је у њиховом „легитимном” националном интересу да остану у заједници са “својом“ матичном државом Србијом. На овај се начин може објаснити висок ниво дистанце која постоји између Срба и Бошњака, као и највећа измерена дистанца према Албанцима. Не треба заборавити, кад говоримо о постојању велике дистанце између Срба и Бошњака, да је између ове две групе у Босни годинама беснео етнички рат. Чак и данас постоји отворени политички конфликт у Босни између српског ентитета (Република Српска) и босанског (Федерација Босне и Херцеговине). Дакле, може се тврдити да од политичких фактора у великој мери зависе етнички односи. Висок ниво етничке дистанце коју смо идентификовали у овом истраживању, у овом погледу даје допринос овој тези. 


\section{REFERENCES / ЛИTEPATУPA}

Bešić, M. (2001). Forms of national consciousness. U: Đukanović, Borislav., B. Kuzmanović, M. Lazić, and M. Bešić. Nation and State. Podgorica. CID.

Bešić, M. (2005). National versus Civic Option in Montenegro. Between Authoritarianism and Democracy, 2.

Bešić, M., \& Spasojević, D. (2018). Montenegro, NATO and the divided society. Communist and Post-Communist Studies, 51(2), 139-150.

Bieber, F. (2003). Montenegrin politics since the disintegration of Yugoslavia. Montenegro in Transition: Problems of Identity and Statehood, 11-42.

Brubaker, R. (1996). Nationalism reframed: Nationhood and the national question in the new Europe. Cambridge University Press.

Colletta, N. J., \& Cullen, M. L. (2000). Violent conflict and the transformation of social capital: Lessons from Cambodia, Rwanda, Guatemala, and Somalia (Vol. 795). World Bank Publications.

Denitch, B. D. (1996). Ethnic nationalism: The tragic death of Yugoslavia. U of Minnesota Press.

Deutsch, K. W. (1955). Nationalism and social communication.

Fearon, J. D., \& Laitin, D. D. (2000). Violence and the social construction of ethnic identity. International organization, 54(4), 845-877.

Gagnon Jr, V. P. (1994). Ethnic nationalism and international conflict: The case of Serbia. International security, 19(3), 130-166.

Giddens, A. (1979). Agency, structure. In Central problems in social theory (pp. 49-95). London: Palgrave.

Kaplan, R. D. (2005). Balkan ghosts: A journey through history. Macmillan.

Kaufman, S. J. (2001). Modern hatreds: The symbolic politics of ethnic war. Cornell University Press.

Keiichi, K. (2007). The issue of independence and ethnic identity in Montenegro. Southeastern Europe, 32(1), 163-180.

Komar, O., \& Živković, S. (2016). Montenegro: A democracy without alternations. East European Politics and Societies, 30(4), 785-804.

Lake, D. A., \& Rothchild, D. (1996). Containing fear: The origins and management of ethnic conflict. International security, 21(2), 41-75.

Malešević, S., \& Uzelac, G. (2007). A Nation囚state without the nation? The trajectories of nation冈formation in Montenegro 1. Nations and Nationalism, 13(4), 695-716.

O’loughlin, J., \& o Tuathail, G. (2009). Accounting for separatist sentiment in BosniaHerzegovina and the North Caucasus of Russia: A comparative analysis of survey responses. Ethnic and Racial Studies, 32(4), 591-615.

Posen, B. R. (1993). The security dilemma and ethnic conflict. Survival, 35(1), 27-47

Sekulić, D., Massey, G., \& Hodson, R. (2006). Ethnic intolerance and ethnic conflict in the dissolution of Yugoslavia. Ethnic and Racial Studies, 29(5), 797-827.

Wark, C., \& Galliher, J. F. (2007). Emory Bogardus and the origins of the social distance scale. The American Sociologist, 38(4), 383-395. 


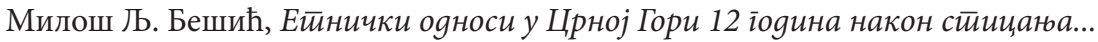

\section{APPENDIX / ПРИЛОЗИ}

Табела 1. Међуетничко дистанцирање по свим ајтемима- проценат одговора НЕ /

Table 1. Inter-ethnic distance for each item/relation - percentage of NO answers

\begin{tabular}{|c|c|c|c|c|c|c|c|c|c|c|}
\hline & & & & & & & & & \\
\hline & & 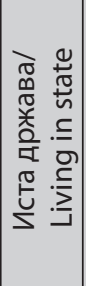 & 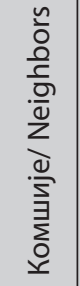 & 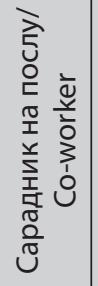 & 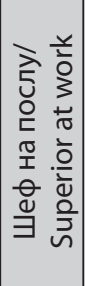 & 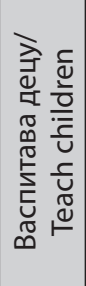 & 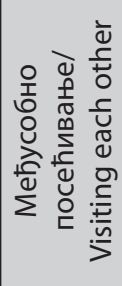 & 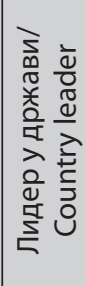 & 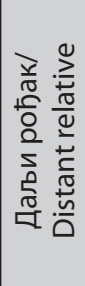 & 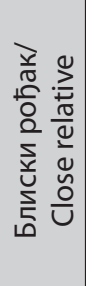 \\
\hline \multirow{4}{*}{$\begin{array}{l}\text { Дистанца } \\
\text { према } \\
\text { Црногорцима/ } \\
\text { Distance } \\
\text { from } \\
\text { Montenegrins }\end{array}$} & $\begin{array}{l}\text { Црногорац/ } \\
\text { Montenegrin }\end{array}$ & - & - & - & - & - & - & - & - & - \\
\hline & Србин/ Serb & 2.8 & 3.5 & 5.3 & 8.9 & 8.5 & 3.2 & 13.5 & 4.6 & 8.9 \\
\hline & $\begin{array}{l}\text { Бошњак/ } \\
\text { Bosniak }\end{array}$ & 4.2 & 5.0 & 7.0 & 16.9 & 16.9 & 14.8 & 22.7 & 54.9 & 65.5 \\
\hline & $\begin{array}{l}\text { Албанац/ } \\
\text { Albanian }\end{array}$ & 6.5 & 13.0 & 19.6 & 26.1 & 28.3 & 23.9 & 26.1 & 41.3 & 63.0 \\
\hline \multirow{4}{*}{$\begin{array}{l}\text { Дистанца } \\
\text { према Србима/ } \\
\text { Distance from } \\
\text { Serbs }\end{array}$} & $\begin{array}{l}\text { Црногорац/ } \\
\text { Montenegrin }\end{array}$ & 3.3 & 2.9 & 4.1 & 7.8 & 6.3 & 3.7 & 12.5 & 4.9 & 8.2 \\
\hline & Србин/ Serb & - & - & - & - & - & - & - & - & - \\
\hline & \begin{tabular}{|l} 
Бошњак/ \\
Bosniak
\end{tabular} & 12.0 & 9.9 & 12.7 & 31.0 & 31.0 & 24.6 & 52.8 & 70.4 & 75.4 \\
\hline & $\begin{array}{l}\text { Албанац/ } \\
\text { Albanian }\end{array}$ & 15.2 & 28.3 & 30.4 & 39.1 & 41.3 & 41.3 & 50.0 & \begin{tabular}{|l|}
80.4 \\
\end{tabular} & 89.1 \\
\hline \multirow{4}{*}{$\begin{array}{l}\text { Дистанца } \\
\text { према } \\
\text { Бошњацима/ } \\
\text { Distance from } \\
\text { Bosniaks }\end{array}$} & $\begin{array}{l}\text { Црногорац/ } \\
\text { ontenegrin }\end{array}$ & 10.2 & 12.7 & 15.2 & 24.5 & 25.6 & 16.4 & 40.5 & 39.8 & 57.5 \\
\hline & Србин/ Serb & 22.1 & 27.4 & 28.1 & 45.6 & 49.5 & 35.9 & 63.9 & 65.4 & 77.3 \\
\hline & \begin{tabular}{|l} 
Бошњак/ \\
Bosniak \\
\end{tabular} & - & - & - & - & - & - & - & - & - \\
\hline & $\begin{array}{l}\text { Албанац/ } \\
\text { Albanian }\end{array}$ & 23.9 & 28.3 & 32.6 & 37.0 & 45.7 & 50.0 & 56.5 & 80.4 & 87.0 \\
\hline \multirow{4}{*}{$\begin{array}{l}\text { Дистанца } \\
\text { према } \\
\text { Албанцима/ } \\
\text { Distance from } \\
\text { Albanians }\end{array}$} & $\begin{array}{l}\text { Црногорац/ } \\
\text { Montenegrin }\end{array}$ & 26.2 & 31.4 & 32.6 & 41.8 & 47.2 & 37.5 & 53.3 & 53.8 & 69.4 \\
\hline & Србин/ Serb & 44.5 & 56.6 & 52.3 & 63.3 & 67.3 & 62.6 & 74.4 & \begin{tabular}{|l|}
79.4 \\
\end{tabular} & 84.5 \\
\hline & $\begin{array}{l}\text { Бошњак/ } \\
\text { Bosniak }\end{array}$ & 14.8 & 18.4 & 28.2 & 40.4 & 50.7 & 44.4 & 55.6 & 71.8 & 75.9 \\
\hline & $\begin{array}{l}\text { Албанац/ } \\
\text { Albanian }\end{array}$ & - & - & - & - & - & - & - & - & - \\
\hline
\end{tabular}


Табела 2. Етничко дистанцирање према свакој етничкој групи и укупна дистанца - дистрибуција/

Table 2. Ethnic distance from each group and total distance - distribution

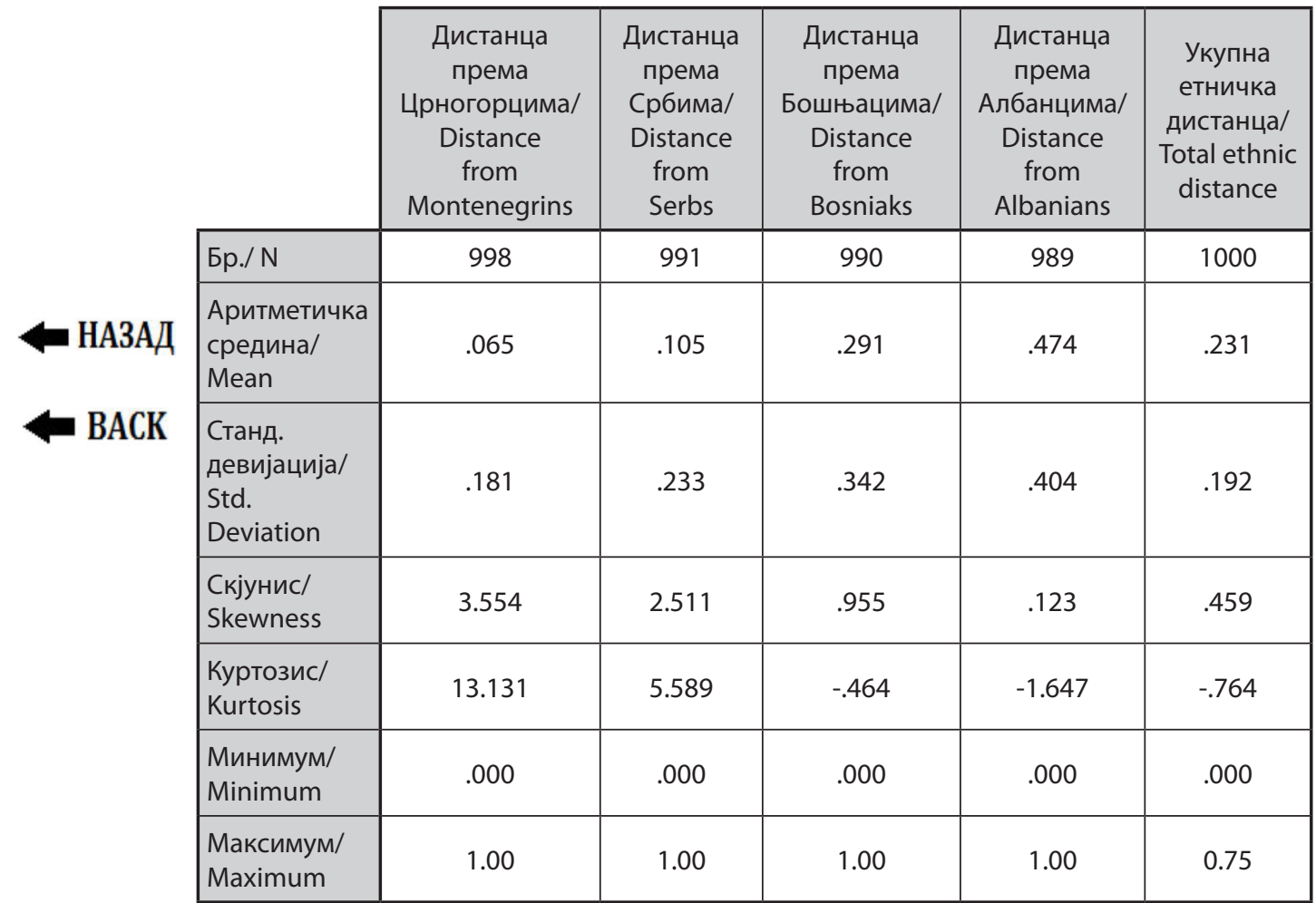

Табела 3. Међуетничко дистанцирање/ Table 3 Inter-ethnic distance

\begin{tabular}{|c|c|c|c|c|c|c|}
\hline & \multirow[b]{2}{*}{$\begin{array}{c}\text { Дистанца } \\
\text { према } \\
\text { Црногорцима/ } \\
\text { Distance } \\
\text { from } \\
\text { Montenegrins }\end{array}$} & \multirow[b]{2}{*}{$\begin{array}{l}\text { Дистанца } \\
\text { према } \\
\text { Србима/ } \\
\text { Distance } \\
\text { from } \\
\text { Serbs }\end{array}$} & \multirow[b]{2}{*}{$\begin{array}{c}\text { Дистанца } \\
\text { према } \\
\text { Бошњацима/ } \\
\text { Distance } \\
\text { from } \\
\text { Bosniaks }\end{array}$} & \multirow[b]{2}{*}{$\begin{array}{c}\text { Дистанца } \\
\text { према } \\
\text { Албанцима/ } \\
\text { Distance } \\
\text { from } \\
\text { Albanians }\end{array}$} & \multirow[b]{2}{*}{$\begin{array}{c}\text { Укупна } \\
\text { етничка } \\
\text { дистанца/ } \\
\text { Total ethnic } \\
\text { distance }\end{array}$} \\
\hline & & & & & & \\
\hline НАЗАД & $\begin{array}{l}\text { Црногорац/ } \\
\text { Montenegrin }\end{array}$ & - & .060 & .269 & .437 & .189 \\
\hline BACK & $\begin{array}{l}\text { Србин/ } \\
\text { Serb }\end{array}$ & .066 & - & .460 & 649 & .292 \\
\hline & $\begin{array}{l}\text { Бошњак/ } \\
\text { Bosniaк }\end{array}$ & .231 & .356 & - & .444 & .256 \\
\hline & $\begin{array}{l}\text { Албанац/ } \\
\text { Albanian }\end{array}$ & .275 & .461 & .490 & - & .307 \\
\hline
\end{tabular}




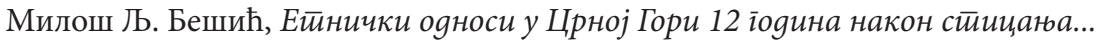

Табела 4. Логистичка регресиона анализа - Предиктори дистанце према свим етничким групама/

Table 4 Logistic regression analysis - predictors of distance from each ethnic group

\begin{tabular}{|c|c|c|c|c|}
\hline $\begin{array}{l}\text { Предиктори/ } \\
\text { Predictors }\end{array}$ & $\begin{array}{c}\text { Модел } 1 \\
\text { Дистанца према } \\
\text { Црногорцима/ } \\
\text { Model1 } \\
\text { Distance } \\
\text { From } \\
\text { Montenegrins }\end{array}$ & $\begin{array}{c}\text { Модел } 2 \\
\text { Дистанца } \\
\text { према } \\
\text { Србима/ } \\
\text { Model2 } \\
\text { Distance } \\
\text { From Serbs }\end{array}$ & $\begin{array}{c}\text { Модел } 3 \\
\text { Дистанца } \\
\text { према } \\
\text { Бошњацима/ } \\
\text { Model3 } \\
\text { Distance From } \\
\text { Bosniaks }\end{array}$ & $\begin{array}{c}\text { Модел } 4 \\
\text { Дистанца } \\
\text { према } \\
\text { Албанцима/ } \\
\text { Model4 } \\
\text { Distance From } \\
\text { Albanians }\end{array}$ \\
\hline $\begin{array}{l}\text { Константа/ } \\
\text { Intercept }\end{array}$ & $\begin{array}{l}-.014 \\
(.031)\end{array}$ & $\begin{array}{l}.051 \\
(.038)\end{array}$ & $\begin{array}{l}-.022 \\
(.064)\end{array}$ & $\begin{array}{l}.062 \\
(.086)\end{array}$ \\
\hline $\begin{array}{l}\text { Мушки/ } \\
\text { Male }\end{array}$ & $\begin{array}{c}.009 \\
(.010)\end{array}$ & $\begin{array}{l}.023^{*} \\
(.012)\end{array}$ & $\begin{array}{c}.017 \\
(.020)\end{array}$ & $\begin{array}{l}-.007 \\
(.024)\end{array}$ \\
\hline $\begin{array}{l}\text { Старост/ } \\
\text { Age }\end{array}$ & $\begin{array}{l}.000 \\
(.000)\end{array}$ & $\begin{array}{c}-.001^{* *} \\
(.000)\end{array}$ & $\begin{array}{l}-.001 \\
(.001)\end{array}$ & $\begin{array}{l}-.001 \\
(-001)\end{array}$ \\
\hline $\begin{array}{l}\text { Средња школа } \\
\text { трећи степен/ } \\
\text { High school third } \\
\text { level }\end{array}$ & $\begin{array}{l}.032 \\
(.021)\end{array}$ & $\begin{array}{l}-.049^{*} \\
(.025)\end{array}$ & $\begin{array}{l}-.055 \\
(.041)\end{array}$ & $\begin{array}{l}-.017 \\
(.050)\end{array}$ \\
\hline $\begin{array}{l}\text { Средња школа } \\
\text { четврти степен/ } \\
\text { High school forth } \\
\text { level }\end{array}$ & $\begin{array}{l}-.025 \\
(.020)\end{array}$ & $\begin{array}{l}-.052^{* *} \\
(.024)\end{array}$ & $\begin{array}{c}-.088^{* *} \\
(.039)\end{array}$ & $\begin{array}{l}-.055 \\
(.047)\end{array}$ \\
\hline $\begin{array}{l}\text { Виша школа/ } \\
\text { Higher education }\end{array}$ & $\begin{array}{l}-.028 \\
(.025)\end{array}$ & $\begin{array}{c}-.088^{* * *} \\
(.030)\end{array}$ & $\begin{array}{l}-.097^{* *} \\
(.048)\end{array}$ & $\begin{array}{l}-.053 \\
(.058)\end{array}$ \\
\hline $\begin{array}{l}\text { Факултет и више/ } \\
\text { University } \\
\text { education } \\
\text { and higher }\end{array}$ & $\begin{array}{l}-.006 \\
(.023)\end{array}$ & $\begin{array}{l}-.066^{* *} \\
(.027)\end{array}$ & $\begin{array}{c}-.170^{* * * *} \\
(.044)\end{array}$ & $\begin{array}{c}-.153^{* * *} \\
(.053)\end{array}$ \\
\hline $\begin{array}{l}\text { Низак приход/ } \\
\text { Low income }\end{array}$ & $\begin{array}{l}.044^{* * *} \\
(.015)\end{array}$ & $\begin{array}{l}.047^{* * *} \\
(.017)\end{array}$ & $\begin{array}{l}.003 \\
(.028)\end{array}$ & $\begin{array}{l}.030 \\
(.034)\end{array}$ \\
\hline $\begin{array}{l}\text { Средњи приход/ } \\
\text { Medium income }\end{array}$ & $\begin{array}{l}-.003 \\
(.014)\end{array}$ & $\begin{array}{l}.011 \\
(.016)\end{array}$ & $\begin{array}{l}.007 \\
(.026)\end{array}$ & $\begin{array}{l}.028 \\
(.032)\end{array}$ \\
\hline $\begin{array}{l}\text { Црногорац/ } \\
\text { Montenegrin }\end{array}$ & $\begin{array}{l}\text { Референца/ } \\
\text { Reference }\end{array}$ & $\begin{array}{l}.076^{* * *} \\
(.014)\end{array}$ & $\begin{array}{l}.378^{* * *} \\
(.032)\end{array}$ & $\begin{array}{l}.466^{* * *} \\
(.059)\end{array}$ \\
\hline $\begin{array}{l}\text { Србин/ } \\
\text { Serb }\end{array}$ & $\begin{array}{l}.053^{* * *} \\
(.012)\end{array}$ & $\begin{array}{l}\text { Референца/ } \\
\text { Reference }\end{array}$ & $\begin{array}{l}.534^{* * *} \\
(.033)\end{array}$ & $\begin{array}{l}.633^{* * * *} \\
(.061)\end{array}$ \\
\hline $\begin{array}{l}\text { Бошњак/ } \\
\text { Bosniak }\end{array}$ & $\begin{array}{l}.192^{* * *} \\
(.017)\end{array}$ & $\begin{array}{l}.315^{* * *} \\
(.021)\end{array}$ & $\begin{array}{l}\text { Референца/ } \\
\text { Reference }\end{array}$ & $\begin{array}{l}.307^{* * *} \\
(.067)\end{array}$ \\
\hline
\end{tabular}




\begin{tabular}{|l|c|c|c|c|}
\hline $\begin{array}{l}\text { Албанац/ } \\
\text { Albanian }\end{array}$ & $\begin{array}{c}.284^{* * *} \\
(.026)\end{array}$ & $\begin{array}{c}.482^{* * *} \\
(.031)\end{array}$ & $\begin{array}{c}.573^{* * *} \\
(.055)\end{array}$ & $\begin{array}{c}\text { R Peференца/ } \\
\text { Reference }\end{array}$ \\
\hline Север/ & $\begin{array}{c}.024 \\
(.016)\end{array}$ & $\begin{array}{c}.040^{* *} \\
(.019)\end{array}$ & $\begin{array}{c}.143^{* * *} \\
(.031)\end{array}$ & $\begin{array}{c}.190^{* * *} \\
(.037)\end{array}$ \\
\hline North & $\begin{array}{l}-.004 \\
\text { Центар/ }\end{array}$ & $\begin{array}{c}-.008 \\
(.016\end{array}$ & $\begin{array}{c}.012 \\
(.026)\end{array}$ & $\begin{array}{c}-.033 \\
(.032)\end{array}$ \\
\hline $\begin{array}{l}\text { Пепитеr } \\
\text { Adjusted } \mathrm{R}^{2}\end{array}$ & .290 & .382 & .240 & .191 \\
\hline
\end{tabular}

${ }^{* * *} \mathrm{p}<.01 \quad{ }^{* *} \mathrm{p}<.01 \mathrm{p}<.1$

У табелама су дати нестандардизовани регресиони коефицијенти. Стандардна грешка коефицијената је пријављена у заградама. Референтна категорија за етницитет је означена у табели, тј. то је етницитет у односу на који се етничка дистанца (зависна) процењује у сваком моделу./

Entries are unstandardized regression coefficients. The standard error of coefficients is reported in parentheses. The reference category for ethnicity is indicated in the table, i.e. it is the ethnicity from which the ethnic distance (dependent) in each model is estimated. 